\title{
Oral health conditions and quality of life of elderly users of the Unified National Health System
}

\author{
Condições de saúde bucal e qualidade de vida de idosos usuários do Sistema Único de Saúde
}

Soraya Fernandes MESTRINER ${ }^{1}$

Aline dos Santos Queiroz de ALMEIDA'

Luana Pinho de MESQUITA' ${ }^{1}$

Alexandre Fávero BULGARELLI²

Wilson MESTRINER JUNIOR'

\section{ABSTRACT}

\section{Objective}

This study aimed to analyze the oral health status and socio-economic conditions of the elderly, which are users of the Brazilian Unified Public Health System (SUS) and its relationship to a subjective indicator of impacts of oral conditions on quality of life (Oral Health Impact Profile OHIP-14).

\section{Methods}

It is a descriptive cross-sectional exploratory study developed in the second semester of 2011. The sample consisted of 76 elderly (65-74 years old) users of the public dental service at the Dental Specialties Center at the Faculty of Dentistry of Ribeirão Preto, Brazil. The methodological strategy adopted for data collection was the structured interview and secondary data were obtained from medical records and reports. To perform the statistical analysis it was used an exploratory analysis of multivariate data by means of STATA Software.

\section{Results}

The frequencies of the dimensions of the OHIP-14 with the greatest impact were pain (13.16\%) and psychological distress (14.47\%). The low impact association was represented by social disability (71\%) and social disadvantage (63\%). The gender, type of housing, necessity and prosthesis wearing were not associated with measures of quality of life related to oral health. It was observed a good correlation between the perception $(r=0.542, p<0.001)$, a moderate association between higher income $(r=0.28, p<0.01)$ and the scores of the OHIP.

\section{Conclusion}

It was concluded that the elderly which reported good self-perception of oral health and good income have expressed the perception that oral health reflects a good impact on quality of life.

Indexing terms: Health of the elderly. Oral health. Quality of life.

\section{RESUMO}

\section{Objetivo}

Analisar as condições de saúde bucal e sócio-econômicas de idosos usuários do Sistema Único de Saúde na unidade de referência Faculdade de Odontologia de Ribeirão Preto da Universidade de São Paulo, bem como sua relação com um indicador subjetivo de impactos das condições bucais na qualidade de vida. Trata-se de um estudo descritivo transversal exploratório.

\section{Métodos}

O grupo de entrevistados foi constituído por 76 idosos mentalmente capacitados, independentes fisicamente, ambos os sexos, com 60 anos ou mais. A coleta de dados aconteceu por meio da aplicação do questionário sobre autopercepção em saúde bucal, Oral Health Impact Profile - OHIP-14 e os dados secundários obtidos dos prontuários dos pacientes atendidos na referida unidade de referência.

\section{Resultados}

Na amostra, 69,74\% eram do gênero feminino, 59\% tinham 60 a 69 anos (média de 68,5 anos). As frequências das dimensões com maior impacto foram: dor (13,16\%) e desconforto psicológico (14,47\%); menor impacto, incapacidade social (71\%) e desvantagem social (63\%). As variáveis gênero, tipo de moradia, necessidade e uso de próteses não tiveram associação com as medidas de qualidade de vida relacionada à saúde bucal. Foi observada uma boa correlação entre autopercepção e os escores do OHIP-14 ( $r=0.542, p<0.001)$ e uma associação moderada $(r=0.28, p<0,01)$ entre maior renda e os escores do OHIP-14.

\section{Conclusão}

Concluiu-se que autopercepção em saúde bucal e renda dos idosos expressaram impacto percebido de sua saúde bucal sobre a qualidade de vida.

Termos de indexação: Saúde bucal. Saúde do idoso. Qualidade de vida.

\footnotetext{
${ }^{1}$ Universidade de São Paulo, Faculdade de Odontologia, Departamento de Estomatologia, Saúde Coletiva e Odontologia Legal. Av. do Café, s/n., Monte Alegre, 14040-904, Ribeirão Preto, SP, Brasil. Correspondência para / Correspondence to: SF MESTRINER. E-mail:<somestri@forp.usp.br>.

${ }^{2}$ Universidade Federal do Rio Grande do Sul, Faculdade de Odontologia, Departamento de Odontologia Preventiva e Social. Porto Alegre, RS, Brasil.
} 


\section{INTRODUCTION}

The world's population is reaching increasingly higher age groups and the number of elderly is increasing over the years. Thus, the elderly have become a part of the population that requires specific care and dental care models leading to preventive, rehabilitative, curative, humanized assistant levels. This paradigm of care, offered in the Faculty of Dentistry of Ribeirão Preto (SP), aims to ensure the elderly access to oral health actions fully and equitably. In this context, certain indicators such as quality of life, oral health conditions and also socio-demographic indicators are critical to the user, compared the dental services provided, to be satisfied and have a good quality of life.

Brazil, similar to several developing countries, is aging rapidly. The elderly population, people aged 60 years or more, is the population segment that grows faster in this country. It is estimated that in 2020, Brazil will be the sixth largest elderly population in the world, with nearly 32 million peolple?

In the global context, there is a concern about elderly oral health, because it is directly linked to the quality of life of this population, since this quality determination is fundamentally related to the living conditions, public health policies, as well as intersectoral actions. In a globalized way, the elderly oral health is poor, so it is recommended that public health programs encompass oral health population, especially the elderly ${ }^{1-2}$.

The progressive loss of the dental elements and the use of dentures result in great damage to the elderly health, compromising their ability to chew, and may also cause loss of appetite, digestion and phonation, difficulties in social relations and behavioral changes ${ }^{3-4}$.

It is understood that for the elderly, health means an instrument for continuation of life. For them, to be healthy is to feel well and be able to carry out their activities properly ${ }^{5}$. Culturally, some situations are still socially "acceptable" in aging groups, such as dental loss, the use of unsuitable dentures and halitosis. In certain cases, toothless people consider dental loss a normal event in aging process ${ }^{6}$.

The meaning of oral health for the elderly has association with several factors of different approaches such as the presence of pain in the oral cavity, lack of natural teeth that make it difficult to chew, appointment with the dental surgeon and aesthetic ${ }^{7}$. Under this assumption, the self-perception can be related to some clinical factors, such as number of decayed, missing or restored teeth ${ }^{8}$ and to subjective factors, such as disease symptoms and people ability to smiling, talking or chewing smoothly. Such indicators should consider the individual's perception about their own oral health, measuring the impact of this perception in daily activities and social performance ${ }^{9}$.

Health perception constitutes a subjective indicator of state of health that has been applied systematically in measuring health status for its predictive power in the individual survival rate. Data on selfperception are subjective, and for their collection, some authors have standardized questionnaires to assess the functional, social and psychological problems due to oral diseases. When choosing the tools to evaluate the quality associated with oral health in elderly, short questionnaires seem to have more advantages ${ }^{10}$. These instruments are designed to add information to clinical indicators routinely used by dentists and has as potential benefit, the classification of groups care needs ${ }^{10}$.

Among several instruments developed to measure perceived needs, the Oral Health Impact Profile (OHIP) is one of the most widely used in studies of different cultures and socio-demographic profiles. OHIP was developed to provide a comprehensive measurement of dysfunction, discomfort and disability attributed to oral conditions ${ }^{11}$. Such information aims to complement the traditional oral epidemiology indicators for clinical diseases and thus, provide a profile of the diseases impact in populations and effectiveness of health services to reduce these impacts ${ }^{12}$.

From the foregoing, it is understood that working with this research object, which is designed as the association between self-perceived oral health and quality of life of older people, is a fundamental element to understand the relationship between oral health practices for older people in public health system and the achievement of good quality of life. Thus, this study was conducted in order to analyze the oral health status and socio-demographic conditions of elderly Unified National Health System (SUS) users, and the relationships with a subjective indicator of oral conditions impact on quality of life (OHIP -14).

\section{METHODS}

This current research is a descriptive cross-sectional exploratory study with primary data from structured interviews and secondary data from elderly records in the Dental Clinics of the Dentistry School of Ribeirão Preto, University of São Paulo (FORP-USP).

The study was conducted at the named University in Ribeirão Preto, which is one of the largest 
cities in the state of São Paulo with an urban area of $274 \mathrm{~km}^{2}$. It is considered a medium-sized city selfperceived oral health questionnaire distant $313 \mathrm{~km}$ from the capital. Ribeirão Preto has more than 500,000 inhabitants $(563,107$ inhabitants) with a growth rate of 1,66 inhabitants per year, and $12.7 \%$ of people aged over 60 years ${ }^{13-14}$

The study population consisted of elderly aged 60 years or more, who were in attendance in the dental clinics of Undergraduate students of FORP-USP. From the total population of elderly people those with suggestion of mental illness identified by the Mini Mental State Examination (MMSE), disabled people, as well as seniors who refused to participate in the study were excluded. A sample of the total population was calculated based on a margin of error equal to $7 \%$ for a confidence interval of $93 \%$. The study sample was of 95 senior citizens.

To collect the primary data, the OHIP-14 ${ }^{11}$ instrument was applied along with a self-perceived oral health questionnaire ${ }^{15-18}$. Information on oral health conditions, such as edentulous ones, were obtained from patient records, after the identification of elderly registered in the FORP-USP Clinical System database. For the OHIP instrument application, the researcher proceeded reading each question, and after reading it, the elderly freely selected the answer for each question, among five options, as the Likert scale: always, often, sometimes, rarely, never. Self-perceived oral health was based on the general assessment criterion: do not know / not reported, very poor, poor, fair, good or excellent.

A pre test with application of the three instruments of data collection was performed in 10 patients. In this situation it was verified that there was no difficulty referring to the instrument issues understanding, the time spent and site chosen for the development of the activity.

The data were tabulated in a spreadsheet in Microsoft Excel ${ }^{\circledR}$ Program 2003 version which allowed the ordering of data according to the objective to be checked, the calculation of the OHIP-14, and also was possible to calculate averages and percentages for sample characterization, according to the listed variables. Statistical analysis was performed using the MannWhitney or Kruskal-Wallis test and PASW Statistics (version 18, SPSS, Inc., Chicago, IL, USA) respecting a significance level of 0.05 .

This study was based on research mode for minimal risk and was conducted after approval from the Faculty of Dentistry of Ribeirão Preto Research Ethics Committee, University of São Paulo (Case No. 2008.1.1301.58.5)

\section{RESULTS}

Were effectively evaluated 76 elderly, considering that there was a sample loss of $20 \%$ due to the consent absence and exclusion due to missing data in the patients records. The participants were in the age range of 60 86 years, and 53 were female, representing a sample feminization (69.74\%).

Table 1 shows the frequency responses of the smallest and largest value in each considered dimension (OHIP-14). Sociodemographic characteristics, oral health conditions, sample oral health perception and the correlation with the OHIP-14 can be seen in Table 2 and 3 .

For statistical analysis a score with the sum of all

Table 1. Simple frequency of responses of lower and higher impact on the seven studied dimensions. Elderly treated in the FORP-USP dental clinic. Ribeirão Preto, 2010

\begin{tabular}{lcc}
\hline OHIP-14 Dimension & $\begin{array}{c}\text { Lower assigned } \\
\text { value }\end{array}$ & $\begin{array}{c}\text { Higher assigned } \\
\text { value }\end{array}$ \\
\hline Functional limitation & $57,24 \%$ & $7,24 \%$ \\
Physical pain & $48,03 \%$ & $13,16 \%$ \\
Psychological discomfort & $50,66 \%$ & $14,47 \%$ \\
Physical disability & $55,92 \%$ & $8,55 \%$ \\
Psychological disability & $46,05 \%$ & $7,24 \%$ \\
Social disability & $71,05 \%$ & $5,26 \%$ \\
Handicap & $63,16 \%$ & $2,63 \%$ \\
\hline
\end{tabular}

Table 2. OHIP-14 Results according to qualitative independent variables. Elderly treated in the FORP-USP Dental Clinic. Ribeirão Preto (SP), 2010

\begin{tabular}{|c|c|c|c|c|c|}
\hline Dependent variable & $\mathrm{n}$ & $\%$ & Median & Quartiles & $p^{\dagger}$ \\
\hline \multicolumn{6}{|l|}{ Gender } \\
\hline Female & 52 & 69,74 & 11,5 & $3-23,8$ & \multirow{2}{*}{0,440} \\
\hline Male & 24 & 30,26 & 8 & $1,5-22,5$ & \\
\hline \multicolumn{6}{|l|}{ Habitation } \\
\hline Own house & 53 & 69,74 & 10 & $2,5-23$ & \multirow{4}{*}{0,386} \\
\hline In acquisition & 6 & 7,89 & 10 & $0-21$ & \\
\hline Rented & 6 & 7,89 & 9 & $1,5-41,3$ & \\
\hline Ceded & 11 & 14,47 & 17 & $9-26$ & \\
\hline \multicolumn{6}{|l|}{ Prothesis Need } \\
\hline No need & 23 & $30 \%$ & 11 & $3-23$ & \multirow{4}{*}{0,823} \\
\hline $\begin{array}{l}\text { Fixed partial } \\
\text { denture }\end{array}$ & 9 & $12 \%$ & 15 & $8-21$ & \\
\hline $\begin{array}{l}\text { Removable } \\
\text { partial denture }\end{array}$ & 6 & $8 \%$ & 6 & $3,5-16,5$ & \\
\hline $\begin{array}{l}\text { Complete } \\
\text { denture }\end{array}$ & 38 & $50 \%$ & 11,5 & $1,8-25$ & \\
\hline \multicolumn{6}{|l|}{ Prothesis Use } \\
\hline None & 23 & $30 \%$ & 13 & $1-23$ & \multirow{4}{*}{0,906} \\
\hline FPD & 4 & $5 \%$ & 16 & $9,8-17,8$ & \\
\hline RPD & 6 & $8 \%$ & 8,5 & $4,8-30$ & \\
\hline$C D$ & 43 & $57 \%$ & 9 & $2-25$ & \\
\hline \multicolumn{6}{|c|}{ Selfperceived oral health } \\
\hline Very poor & 4 & $5.26 \%$ & 27 & $18,5-40$ & \multirow{5}{*}{$<0,001$ * } \\
\hline Poor & 12 & $15,79 \%$ & 21 & $15,8-30$ & \\
\hline Fair & 20 & $26,32 \%$ & 14 & $6,3-23$ & \\
\hline Good & 31 & $40,79 \%$ & 5 & $0-13$ & \\
\hline Excellent & 9 & $11,84 \%$ & 2 & $0-6,5$ & \\
\hline
\end{tabular}


Table 3. Correlation between OHIP-14 and other quantitative variables. Elderly treated in the FORP-USP Dental Clinic. Ribeirão Preto (SP), 2010.

\begin{tabular}{|c|c|c|c|c|c|}
\hline \multicolumn{2}{|c|}{ Dependent variable } & \multirow{2}{*}{$\begin{array}{l}\mathrm{n} \\
\\
45 \\
21 \\
10\end{array}$} & \multirow{2}{*}{$\begin{array}{c}\% \\
59,21 \% \\
27,63 \% \\
13,16 \%\end{array}$} & \multirow{2}{*}{$\begin{array}{c}r \\
-0,05\end{array}$} & \multirow{2}{*}{$\begin{array}{c}P \\
0,68\end{array}$} \\
\hline Age & $\begin{array}{l}60 \text { a } 69 \\
70 \text { a } 79 \\
80 \text { a } 89\end{array}$ & & & & \\
\hline Scholarity & $\begin{array}{c}0 \text { a } 4 \text { anos } \\
5 \text { a } 8 \text { anos } \\
9 \text { ou }+ \text { anos }\end{array}$ & $\begin{array}{c}55 \\
12 \\
9\end{array}$ & $\begin{array}{l}72,37 \\
15,79 \\
11,84\end{array}$ & $-0,02$ & 0,87 \\
\hline Family Income & $\begin{array}{c}0 \mid---0,5 \mathrm{SM} \\
0,6 \mid--1 \mathrm{SM} \\
1,1 \mid--1,6 \mathrm{SM} \\
1,7 \mid--2 \mathrm{SM} \\
+2,1 \mathrm{SM}\end{array}$ & $\begin{array}{l}17 \\
32 \\
12 \\
9 \\
6\end{array}$ & $\begin{array}{l}22 \\
42 \\
16 \\
12 \\
8\end{array}$ & $0,28 *$ & 0,01 * \\
\hline
\end{tabular}

* Significant correlation. $r$ - moderate association

OHIP-14 issues was calculated in order to analyze their results in terms of other variables. The distribution of values does not adhere to the normal even after logarithmic transformation. The respective median and quartiles were grouped according to each level of the independent variable results, and compared using the Mann-Whitney or Kruskal-Wallis test depending on the number of levels.

Concerning the prosthesis need, a transformation was performed to summarize the number of possible directions and provide a hierarchy between levels. Four levels were considered: (0) No need, (1) fixed partial denture (FPD) upper and / or lower, only; (2) removable partial denture (RPD) opposite the RPD, FPD, CD, or none, and (3) complete denture (CD) upper and / or lower. For other variables, we calculated the Spearman correlation coefficient with the scores of the OHIP-14. All tests were done using PASW Statistics (version 18, SPSS, Inc., Chicago, $\mathrm{IL}$, USA), and with a significance level of 0.05 program.

\section{DISCUSSION}

This is a study that tried to work out some issues involving oral health and quality of life of elderly people assisted in the Unified National Health System with access to care in the Ribeirão Preto Dental School. In the present study, were observed associations for some dimensions of the OHIP instrument, not being covered all dimensions in the analysis. In the search for associations to contextualize this research object was observed that factors as age, type of housing, need and use of prostheses were not associated with measures of quality of life related to oral health. Moreover, different levels of self-perceived oral health resulted in different median scores for OHIP-14. In the case of association between self perception and OHIP-14 scores, was found good correlation between the two variables $(r=$ $-0.542, p<0.001$ ). Participants with better self-perception tend to present lower OHIP-14 values.

There was no association between qualitative variables and quality of life related to oral health, except for per capita income. In this case, there was a moderate association, which represents a participants' tendency with higher income express higher perceived impact of their oral health on quality of life, which is contrary to that observed in other studies where this association was not found ${ }^{15}$.

In the present study, the pursuit for a wider and more accurate diagnosis led researchers to deal with subjective measures that complement the clinical examination, aiming to insert the patient's own perception of their oral health status as a relevant factor to dental care. These data provide the professional with an integral view of the patient and their health. Besides clinical features, it is possible that the geriatric patient subjective perception is taken into account, leaving behind the biomedical model, which is based only on diseases identification ${ }^{16}$.

The questionnaire used in this study (OHIP-14) has as its basic purpose to work the patient self-perception regarding their oral health and how it interferes in daily life and quality of life ${ }^{17}$, stating how the oral condition impact in quality of life of these individuals. From the data obtained with this indicator, the variables Psychological Discomfort and Physical Pain were the dimensions of greatest impact on quality of life of interviewed elderly. These data are in accordance with the results presented in literature ${ }^{4}$ in which through OHIP-14 was proved that the aspects that most annoy edentulous patients is the shame of not having teeth (dimension psychological disability), the discomfort to eat (dimension physical pain), the concern with the mouth (dimension psychological discomfort) and feed injury (dimension physical disability).

Most respondents reported having never faced problems regarding Social Disability (71\%) and Handicap (63\%) dimensions (Table 1). No relationship between age, scholarity and number of teeth with self-perceived oral health was found.

According to the latest survey on oral health conducted by the Ministry of Health in Brazil, there are 30 million edentulous in the country, $88.46 \%$ of the elderly population (65-74 years) need some type of dental prosthesis and $39,96 \%$ need complete dentures ${ }^{18}$. The data suggest that the more aged, higher are the indices of edentulous people, then the aging process is a fact highly associated with the need to use complete dentures in Brazilian population. The World Health Organization (WHO) expected to find, in 2000, $50 \%$ of people aged from 
65 to 74 years with 20 or more teeth in the mouth, but the country has reached the percentage of only $10.23 \%{ }^{19}$.

In the present study, $50 \%$ of elderly people need complete dentures, and, as highlighted in the literature, more than half of complete dentures were registered as needing replacement ${ }^{19}$. While the dentist evaluates the condition based on the presence or absence of disease, the patient gives more importance to symptoms and functional and social problems that may be triggered by the presence of the disease ${ }^{17}$. In this context, it is observed in the literature that some studies have shown differences between clinical conditions and patient self-perception ${ }^{20}$.

As the dental services universality is still restricted in the Brazilian public service, it is believed that to know the perception of SUS users about their oral condition should be an important step to develop programs and programmatic actions that include educational activities focused on selfdiagnosis and care, as well as preventive and curative actions ${ }^{21}$.

Although the oral health conditions in this age group are still presented as unsatisfactory, with high rates of edentulism, reflecting the historical inefficacy of public dental services, limited to serial extractions and emergency services, based on the curative model, self perception was very positive and most participants were satisfied with their oral health as evidenced in the study of Silva et al. ${ }^{22}$. Regarding this, it was highlighted through the use of OHIP14 that $60.5 \%$ of the study population showed no impact of oral conditions on quality of life ${ }^{23-24}$. It was also observed that people with higher average number of impacts identified a worse oral health, and reported more problems with their teeth and/or gums ${ }^{17}$. As in the Andrade et al. ${ }^{25}$ study, self-assessment of poor oral health was associated with general health factors and the psychosocial impact of oral health on quality of life, regardless of socioeconomic and clinical measures of oral health.

The impacts related to the difficulty of making obligations and total activities disability scored lower percentages in the total sample (Table 3). These findings are confirmed by most studies investigating these impacts ${ }^{24}$ and also, that changes in oral health affected negatively in

\section{REFERENCES}

1. Lima Costa MF, Veras R. Saúde pública e envelhecimento. Cad Saúde Pública. 2003;19(3):700-1. doi: 10.1590/S0102$311 \times 2003000300001$

2. World Health Organization. Active ageing: a policy framework. 2002 Geneva: World Health Organization; 2002 [cited 2013 Dez 5]. Available from: <http://whqlibdoc.who.int/hq/2002/WHO_ NMH_NPH_02.8.pdf>. the quality of life of people as the study of Locker \& Allen ${ }^{26}$ who found that physical pain is within the questions most affected by changes in oral health.

Most respondents of this study are edentulous, a fact that may be associated with the current Brazilian elderly population, that had no access to dental care with a preventive strategy for dental care, present high prevalence of edentulism and use of dentures, whether total or partial, for replacement of loss teeth ${ }^{27}$.

The elderly health care services involve a significant demand for resources. The growth trend of elderly population makes it impossible to the Unified National Health System to provide full health care coverage for this population segment, which certainly becomes necessary to select interventions that are effective.

\section{CONCLUSION}

For the diagnosis of the elderly main oral needs it becomes necessary to know not only their objective needs (clinical), but also the subjective ones (reported). Thus, despite the limitations of the study due to the small elderly sample, it is concluded that for elderly treated in this unit, self-perceived oral health in old age and family income per capita expressed a positive association between the perceived impact of their own oral health and quality of life.

These results are relevant for oral health professionals, as they can enlarge their knowledge about the elderly and improve their care ability. The results collaborate for better planning of promotion, protection and recovery of health to be developed, priority, considering the characteristics of the epidemiological profile of the elderly population, not only in terms of prevalent diseases, but socioeconomic conditions and their perceived health needs.

\section{Collaborators}

SF MESTRINER, ASQ ALMEIDA, LP MESQUITA, AF BULGARELLI e W MESTRINER JUNIOR participated in all stages of this article preparation.

3. Bulgarelli AF, Manço ARX. Idosos vivendo na comunidade e a satisfação com a própria saúde bucal. Ciênc Saúde Coletiva. 2008;13(4):1165-74. doi: 10.1590/S141381232008000400012

4. Silva MES, Villaca EL, Magalhaes CS, Ferreira EF. Impacto da perda dentária na qualidade de vida. Ciênc Saúde Coletiva. 2010 [citado 2013 Nov 5];15(3):841-50. Disponível em: <http:// www.scielo.br/scielo.php?script=sci_arttext \&pid=S1413$81232010000300027 \& \operatorname{lng}=e n \& n r m=i s o>$. doi: 10.1590/ S1413-81232010000300027. 
5. Ferrari MAC. O envelhecer no Brasil. O mundo da Saúde. 1999;1:197-203.

6. Ekanayake L, Perera I. Validation of a Sinhalese translation of the oral health impact profile-14 for use with older adults. Gerodontology. 2003;20(2):95-9. doi: 10.1111/j.17412358.2003.00095.x

7. Reis SCGB, Marcelo VC. Saúde bucal na velhice: percepção dos idosos, Goiânia, 2005. Ciênc Saúde Coletiva. 2006;11(1):191-9. doi: 10.1590/S1413-81232006000100028

8. Steele JG, Ayatollahi SMT, Walls AWG, Murray JJ. Clinical factors related to reported satisfaction with oral function amongst dentate older adults in England. Community Dental Oral Epidemiol. 1997;25(2):143-9.

9. Mesquita $F A B$, Vieira S. Impacto da condição autoavaliada de saúde bucal na qualidade de vida. RGO - Rev Gaúch Odontol. 2009;57(4):401-6.

10. Hebling E, Pereira AC. Oral health-related quality of life: a critical appraisal of assessment tools used in elderly people. Gerodontology. 2007;24(3):151-61. doi: 10.1111/j.17412358.2007.00178.x

11. Slade GD, Spencer AJ. Development and evaluation of the oral health impact profile. Community Dent Health. 1994;11(1):311.

12. Slade GD. Derivation and validation of a short-form oral health impact profile. Commun Dent Oral Epidemiol. 1997;25(4):28490.

13. Instituto Brasileiro de Geografia e Estatística. Resultados da amostra do censo demográfico 2000: malha municipal digital do Brasil - situação em 2001. Rio de Janeiro: IBGE; 2004.

14. Ribeirão Preto. Plano Municipal de Saúde: 2010-2013 [citado 2013 Nov 5]. Disponível em: <http://ribeirão preto.sp.go.br/ índex.htmal>.

15. Martins AMEBL, Barreto SM, Silveira MF, Santa-Rosa TTA, Pereira RD. Autopercepção da saúde bucal entre idosos brasileiros. Rev Saúde Pública; 2010 [citado 2013 Nov 5];44(5):912-22. Disponível em: <http://www.scielo.br/scielo.php?script=sci_ arttext\&pid=S0034-89102010000500017\&lang=pt $>$. doi: $10.1590 /$ S0034-89102010005000028

16. Brasil. Ministério da Saúde. Conselho Nacional de Saúde. $3^{a}$ Conferência Nacional de Saúde Bucal: acesso e qualidade superando exclusão social. Brasília: Ministério da Saúde; 2005 [citado 2013 Nov 7]. Disponível em: <http://bvsms.saude.gov. br/bvs/publicacoes/3_conferencia_nacional_saude_bucal_ relatorio_final.pdf>.

17. Bortoli $D$, Locatelli FA, Fadel CB, Baldani MH. Associação entre percepção de saúde bucal e indicadores clínicos e subjetivos: estudo em adultos de um grupo de educação continuada da terceira idade. Publ UEPG Ci Biol Saúde. 2003;9(3/4):55-65.
18. Brasil. Projeto SB Brasil: condições de saúde bucal da população brasileira - resultados principais. Brasília: Ministério da Saúde; 2003. [citado 2013 Nov 7]. Disponível em: <http://cfo.org.br/ wp-content/uploads/2009/10/04_0347_M.pdf>.

19. Fédération Dentaire Internacionale. Global goals for oral health in the year 2000. Int Dent J. 1982;32:1.

20. Bianco VC, Lopes ES, Borgato MH, Silva PM, Marta SN. O impacto das condições bucais na qualidade de vida de pessoas com 50 ou mais anos de vida. Ciênc Saúde Coletiva. 2010;15(4):216572. doi: 10.1590/S1413-81232010000400030

21. Haikal DS, Paula AMB, Martins AMEBL, Moreira NA, Ferreira EF. Autopercepção da saúde bucal e impacto na qualidade de vida do idoso: uma abordagem quanti-qualitativa. Ciênc Saúde Coletiva. 2009 [citado 2013 Nov 5];16(7):3317-29. Disponível em: <http://www.cienciaesaudecoletiva.com.br/artigos/artigo_ int.php?id_artigo $=4646>$.

22. Silva DD, Sousa MLR, Wada RS. Autopercepção e condições de saúde bucal em uma população de idosos. Cad Saúde Pública. 2005 [citado 2013 Nov 5];21(4):1251-9. Disponível em: <http:// www.scielo.br/scielo.php?script=sci_arttext\&pid=S0102$311 \times 2005000400028 \&$ lang=pt>. doi: 10.1590/S0102$311 \times 2005000400028$

23. Henriques $C$, Telarolli Júnior R, Loffredo LCM, Montandon $A A B$, Campos JADB. Autopercepção das condições de saúde bucal de idosos do município de Araraquara/SP. Ciênc Odontol Bras. 2007;10(3):67-73.

24. Moreira RS, Nico LS, Tomita NE, Ruiz T. A saúde bucal do idoso brasileiro: revisão sistemática sobre o quadro epidemiológico e acesso aos serviços de saúde bucal. Cad Saúde Pública. 2005;21(6):1665-75. doi: 10.1590/S0102$311 \times 2005000600013$

25. Andrade FB, Lebrão ML, Santos JL, Duarte YA, Teixeira DS. Factors related to poor self-perceived oral health among community-dwelling elderly individuals in São Paulo, Brazil. Cad Saúde Pública. 2012 [citado 2013 Nov 5];28(10):1965-75. Disponível em: <http://www.scielo.br/scielo.php?script=sci_ arttext\&pid=S0102-311X2012001000014\&lang=pt >. doi: $10.1590 / S 0102-311 \times 2012001000014$

26. Locker D, Allen PF. Developing short-form measures of oral health-related quality of life. J Public Health Dent. 2002;62(1):1320.

27. Dini EL, McGrath C, Bedi R. An evaluation of the oral health quality of life (OHQoL) instrument in a Brazilian population. Community Dent Health. 2003;20(1):40-4.

Received on: 27/5/2014 Final version resubmitted on: 10/9/2014 Approved on: 23/9/2014 